\title{
NIEDOSZLA WYSTAWA PRAC FELIKSA TOPOLSKIEGO W MUZEUM NARODOWYM W 1956 ROKU
}

\author{
Krzysztof TARKA (Instytut Historii, Uniwersytet Opolski)
}

W połowie lat pięćdziesiątych XX wieku władze PRL złagodziły dotychczasowy zdecydowanie negatywny kurs wobec emigracji. Deklarując chęć „,pojednania” z wychodźstwem, dążono do nawiązania bezpośrednich kontaktów nie tylko z emigracyjnymi działaczami politycznymi i społecznymi, ale także z przebywającymi na Zachodzie pisarzami czy artystami. Jedną z takich osób był mieszkający w Londynie znany malarz i rysownik Feliks Topolski.

Latem 1955 roku dyrektor Muzeum Narodowego w Warszawie Stanisław Lorentz i szef Państwowego Instytutu Kultury Juliusz Starzyński zaproponowali Topolskiemu zorganizowanie wystawy jego obrazów w Polsce. Deklarowali też chęć zakupienia kilkunastu dzieł artysty. Równocześnie redaktor naczelny tygodnika „Świat” Stefan Arski wystąpił z propozycją druku rysunków Topolskiego na łamach redagowanego przez siebie pisma. Kontakt $z$ emigracyjnym malarzem nawiązał również przebywający w Londynie Jan Kott, krytyk literacki i teatralny, profesor Uniwersytetu Warszawskiego ${ }^{1}$. Ten nagły wzrost zainteresowania Topolskim i jego twórczością nie był przypadkowy. Za tymi rzekomo „prywatnymi” inicjatywami stały komunistyczne władze. Rozmowy z Topolskim były elementem szerszej akcji politycznej wobec emigracji i Polonii.

Kott wystąpił w roli pośrednika między ambasadorem PRL w Wielkiej Brytanii Eugeniuszem Milnikielem a Topolskim. W pierwszych dniach sierpnia 1955 roku przyprowadził Topolskiego na kolację do peerelowskiego dyplomaty. W rewanżu Topolski zaprosił ambasadora do swojej pracowni, a potem na lunch. Choć Topolski od dwudziestu lat mieszkał w Londynie, zachował żywy sentyment do ojczystego kraju. $\mathrm{Z}$ rozmów z artystą Milnikiel wywnioskował, że „chce on utrzymać bliższy kontakt

\footnotetext{
${ }^{1}$ Archiwum Ministerstwa Spraw Zagranicznych (dalej: AMSZ), Departament III (dalej: D III), z. 9, w. 42, t. 557, k. 19, Pismo E. Milnikiela do MSZ z 18 maja 1956.
} 
z nami” ${ }^{2}$ i chętnie przyjmie zaproszenie do odwiedzenia kraju. Topolskiemu zależało, aby władze w Warszawie zaprenumerowały jego magazyn rysunkowy „Topolski’s Chronicle" dla szkół plastycznych czy muzeów w kraju. Milnikiel zauważył również, że Topolski z pewnym lekceważeniem wypowiadał się na temat kół kierowniczych emigracji. Generała Władysława Andersa nazwał np. watażką. Pytając kierownictwo Ministerstwa Spraw Zagranicznych o sugestie ambasador podkreślił, że „Topolski ma tutaj [w Wielkiej Brytanii] wysoką pozycję towarzyską i niewątpliwie utrzymywanie z nim bliższych stosunków może być dla nas korzystne"ె.

Feliks Topolski urodził się 14 sierpnia 1907 roku w Warszawie. W latach $1927-$ 1932 studiował w Szkole Sztuk Pięknych (od 1932 roku była to Akademia Sztuk Pięknych) pod kierunkiem Tadeusza Pruszkowskiego. Był członkiem złożonej z jego uczniów grupy artystycznej — Loży Wolnomalarskiej. Jeszcze podczas studiów Topolski rozpoczął współpracę z satyrycznym tygodnikiem „Cyrulik Warszawski” (pismo ukazywało się do 1934 roku, a jednym z jego redaktorów był Jan Lechoń). Drukował również w „Skamandrze” i „Wiadomościach Literackich”, dla których przysyłał swe reportaże rysunkowe aż do wybuchu II wojny światowej. W 1934 roku zilustrował Polski stownik pijacki: antologia bachiczna Juliana Tuwima. W następnym roku redaktor „Wiadomości Literackich” Mieczysław Grydzewski wysłał Topolskiego wraz z Antonim Sobańskim do Londynu, aby przygotowali reportaż o jubileuszu 25-lecia panowania króla Jerzego V. Sobański miał napisać tekst, a Topolski zilustrować go. Wyjazd do Londynu miał przełomowe znaczenie w życiu i karierze zawodowej Topolskiego. Stolica Wielkiej Brytanii oczarowała młodego artystę, który zdecydował się na stałe zamieszkać nad Tamizą. Sukces wydanego jeszcze w tym samym roku (1935) albumu The London Spectacle stał się początkiem jego wielkiej międzynarodowej kariery. Jako rysownik Topolski współpracował $\mathrm{z}$ wieloma prestiżowymi angielskimi i amerykańskimi pismami („Fortune”, „Life”, „,Illustrated London News”, „Look”, „New Statesman”, „News Chronicle”, „Observer”, „Picture Post”, „Vogue”). W latach 1939-1945, będąc oficerem armii polskiej i artystą wojennym, wykonał wiele rysunków przedstawiających Bitwę o Anglię oraz walki na różnych frontach: w Związku Sowieckim, na Bliskim i Dalekim Wschodzie, w północnej Afryce, we Włoszech i Niemczech. Rysunki drukował w osobnych tekach-albumach: Britain in Peace and War, Russia in War, Three Continents 1944-1945. Współpracował również z emigracyjną prasą: „Wiadomościami Polskimi” i „Nową Polską” (Londyn) oraz „Tygodnikiem Polskim” (Nowy Jork). Topolski ilustrował książki Georga Bernarda Shawa (m.in. Pigmalion), z którym połączyła go bliska przyjaźn (w 1946 roku ukazał się album Portrait of G.B.S.). Swoje

\footnotetext{
${ }^{2}$ Tamże, Pismo E. Milnikiela do MSZ z 11 sierpnia 1955.

${ }^{3}$ Tamże, k. 2. Pracownia Topolskiego mieściła się w centrum Londynu w arkadzie pod mostem kolejowym Hungerford (w pobliżu mostu Waterloo), dziś jest tam muzeum. „Topolski's Chronicle" ukazywała się w latach 1953-1979 w 24 zeszytach rocznie, na czerech arkuszach brązowego papieru, w nakładzie dwóch tysięcy egzemplarzy. Początkowo dwutygodnik drukowany był w Oficynie Poetów i Malarzy należącej do Czesława i Krystyny Bednarczyków. W swojej kronice Topolski zamieszczał rysunkowe reportaże z Londynu i różnych miejsc na świecie, które odwiedzał. Pismo było swego rodzaju unikatem na skalę światową. Według Tymona Terleckiego: „«Kronika» Topolskiego jest jednocześnie dziełem sztuki i dokumentem naszego czasu”; T. Terlecki, ,Kronika” Topolskiego, Wiadomości 1954 nr 11 (415), s. 4; przedruk w: Sztuka polska w Wielkiej Brytanii 1940-2000. Antologia, wybrał, przygotował do druku i wstępem opatrzył M. A. Supruniuk, Toruń 2006, s. 214-217; Z. Kon, Kronika o Topolskim, Wiadomości 1954 nr 38 (442), s. 5; zob. też: Cz. Bednarczyk, W podmostowej arkadzie. Wspomnienia drukarza i wydawcy, Londyn 1988, s. 28-30; J. Kowalik, Czasopiśmiennictwo, [w:] Literatura polska na obczyźnie 1940-1960, red. T. Terlecki, t. 2, Londyn 1965, s. 511.
} 
prace wystawiał w galeriach na całym świecie (Wielkiej Brytanii, Stanach Zjednoczonych, Kanadzie, Indiach, Australii, Włoszech, Szwecji, Portugalii). W 1947 roku artysta otrzymał brytyjskie obywatelstwo. W sierpniu 1948 roku przyjechał w składzie delegacji angielskiej do Wrocławia na Światowy Kongres Intelektualistów w Obronie Pokoju ${ }^{4}$.

Znajomość Topolskiego z Milnikielem coraz bardziej nabierała przyjacielskiego charakteru. 19 sierpnia 1955 roku artysta zaprosił peerelowskiego dyplomatę do swojego domu na kolację. Podczas towarzyskiej pogawędki Topolski żartował, że niezłomni emigranci uważają go za „wtyczkę” Warszawy. Deklarował, że wiosną przyszłego roku chętnie przyjechałby wraz z rodziną do Polski na zaproszenie władz. Ponownie dopytywał się o możliwość prenumeraty „Topolski’s Chronicle” przez krajowe instytucje kulturalne. Opowiadał też o swoim dobrym znajomym - hrabim Janie Tarnowskim, który mieszkał w Szkocji, ale bardzo chciał wrócić na stałe do Polski, albo przynajmniej odwiedzić ojczysty kraj. Milnikiel sugerował przełożonym w MSZ, że propagandowo lepiej byłoby, gdyby Tarnowski odwiedził Polskę, następnie wrócił do Wielkiej Brytanii i wtedy zdecydował się na powrót na stałe:

Dla emigracji - podkreślił — byłby to naprawdę szok, jeśliby hrabia ordynat wracał na stałe do kraju, po odwiedzeniu go ${ }^{5}$.

W połowie października Topolski żalił się radcy ambasady PRL w Londynie Michałowi Żułkosiowi, że choć minęły trzy miesiące, żadna z tych spraw nie została załatwiona, a jego listy pozostały bez odpowiedzi. Był coraz bardziej zniecierpliwiony brakiem wiążących decyzji, gdyż równocześnie miał propozycje zorganizowania wystaw w Nowym Jorku i São Paulo. Nie chciał też dłużej rezerwować obrazów, na które miał już innych kupców. Narzekał, że nie otrzymał również honorarium za rysunki opublikowane w tygodniku „Świat”. Z drugiej strony uskarżał się, że w ,polskim” Londynie rozpoczęto już na niego nagonkę w związku $\mathrm{z}$ planowanym wyjazdem do kraju. Topolski obawiał się, że z jednej strony zostanie zlekceważony przez władze PRL, z drugiej wyklęty przez emigrację ${ }^{6}$.

\footnotetext{
${ }^{4}$ Na podstawie informacji od ambasadora Milnikiela Departament III MSZ opracował „Notatkę dot. Topolskiego Feliksa"; zob.: AMSZ, D III, z. 9, w. 42, t. 557, k. 3. Więcej informacji biograficznych zawierają wydane katalogi wystaw: Feliks Topolski: malarstwo-rysunek, Warszawa 1992; Feliks Topolski: malarstwo — rysunek — grafika, Kraków 1984; Feliks Topolski: prace w zbiorach Muzeum Narodowego. Katalog, Warszawa 1965; Feliks Topolski - reporter rysunku, Częstochowa 2007; Kronika Topolskiego - Topolski's Chronicle, Warszawa 1988. Ilustrowana autobiografia: F. Topolski, Fourteen Letters: Autobiography, London 1988. Twórczość Topolskiego analizowali m.in.: [S. Zahorska] Pandora, Sztuka Feliksa Topolskiego, Wiadomości 1951 nr 17 (265), s. 3; przedruk w: Sztuka polska w Wielkiej Brytanii..., s. 212-214; S. Frenkiel, Topolszczyzna, Wiadomości 1968 nr 11 (1146), s. 4; M. Żuławski, Nowa ksiązka Feliksa Topolskiego, Wiadomości 1977 nr 26 (1631), s. 3; przedruk w: Sztuka polska w Wielkiej Brytanii..., s. 218-220; Z. Broncel, Teatr Topolskiego, Tydzień Polski 1986 nr 4, s. 8-9; S. Kossowska, Czternaście liter szczęścia, Tydzień Polski 1988 nr 13, s. 8; przedruk w: Sztuka polska w Wielkiej Brytanii..., s. 220-222; zob. też: N. Cieślińska, Feliks znaczy szczęśliwy, Przegląd Powszechny 1983 nr 3, s. 378-392; J. Kilian, Feliks Topolski - kronikarz XX wieku, [w:] Między Polska a światem. Kultura emigracyjna po 1939 roku, red. M. Fik, Warszawa 1992, s. 177-184; J. W. Sienkiewicz, Polskie galerie sztuki w Londynie w drugiej polowie XX wieku, Lublin-Londyn 2003, s. 229-233.

${ }_{6}^{5}$ AMSZ, D III, z. 9, w. 42, t. 557, k. 4-5, Pismo E. Milnikiela do MSZ z 23 sierpnia 1955.

${ }^{6}$ Tamże, k. 6, Depesza M. Żułkosia do MSZ z 19 października 1955. Jerzy Zaruba jeszcze w końcu sierpnia 1955, zapowiadając na łamach tygodnika „Świat” wizytę Topolskiego w kraju, miał nadzieję, że „odnośne czynniki skorzystają ze sposobności, i artysta, Polak tak wielkiej
} 
Na łamach londyńskiego „Orła Białego” Janusz Kowalewski w emocjonalnym liście otwartym apelował do Topolskiego, aby nie jechał „do nich” i nie sprzedawał wolności „za miskę niewolniczej kaszy”. Tłumaczył, że cena jaką przyjdzie mu zapłacić za łyk warszawskiego powietrza będzie zbyt wysoka:

Maszyna przemocy totalitarnej jest wielka. Wciąga w swoje tryby delikatnie, nieznacznie; ciągnie długo pod walce coraz ciaśniejsze. Aż z artysty, z twórcy, bogom równego, zrobi... Słonimskiego ${ }^{7}$.

Ostrzegał, że „odwilż” w bloku sowieckim to „pozór i lipa”. Przekonywał Topolskiego, że wizyta w Polsce rządzonej przez Bieruta i Rokossowskiego będzie zdradą etosu emigranta i nadłamie ducha oporu rodaków w kraju. Zapowiadał, że w tej sytuacji jego stopa nie przekroczy już progu pracowni artysty ${ }^{8}$.

Mimo propozycji z Warszawy, sprawa wystawy i zakupu obrazów Topolskiego utknęła w martwym punkcie. W telefonicznej rozmowie Starzyński ustalił co prawda $\mathrm{z}$ artystą, że wystawa jego prac rozpocznie się 1 marca 1956 roku, jednak do końca grudnia nikt się z nim w tej sprawie nie skontaktował. Organizatorzy wystawy nie wypożyczyli żadnego obrazu Topolskiego z brytyjskich muzeów i od prywatnych kolekcjonerów. Topolski żalił się Milnikielowi, że nie otrzymał też z Warszawy pierwszej raty za obrazy, które planowało kupić Muzeum Narodowe. Na obietnicach skończyło się również w przypadku prenumeraty jego kroniki. W tej sytuacji Topolski nie wierzył już w możliwość zorganizowania w ciągu zaledwie dwóch miesięcy dużej wystawy swoich prac. Skarżył się, że potraktowano go niepoważnie, że niepotrzebnie rozgłaszał w Londynie i wśród emigracji wiadomości o wystawie. „Sprawa jest krańcowo kompromitująca" - alarmował ambasador w Londynie, prosząc ministra spraw zagranicznych Stanisława Skrzeszewskiego o osobistą interwencję 9 .

Na początku stycznia 1956 roku ambasador ponownie interweniował w MSZ, tym razem u dyrektora Departamentu III Józefa Winiewicza. Dopytywał się o termin przekazania Topolskiemu pieniędzy za zakupione obrazy. Nalegał też, aby Starzyński jak najszybciej skontaktował się z emigracyjnym artystą. W przeciwnym razie obawiał się, że „utracimy wystawę”. Informował też przełożonych, że według Topolskiego zwłoka spowodowana była zakończeniem okresu „odwilży” w kraju ${ }^{10}$.

W połowie lutego dyrektor Państwowego Instytutu Sztuki zjawił się wreszcie w Londynie. Starzyński sfinalizował zakup kilkunastu obrazów Topolskiego za łączną kwotę trzech tysięcy funtów oraz ustalił szczegóły techniczne związane z planowaną wystawą jego obrazów w kraju. Termin wystawy przesunięto na jesień 1956 roku. Wysłannik Warszawy rozmawiał też z Topolskim na temat prezentacji jego prac w polskim pawilonie na Biennale Sztuki w Wenecji. Ambasada w Londynie przekonywała kierownictwo MSZ, że:

pokazanie prac Topolskiego na Biennale byłoby nie tylko cenną rewindykacją wielkiego polskiego artysty, dokonaną na gruncie międzynarodowym. Z punktu widzenia na-

miary, wykona jakieś większe monumentalne malowidło ścienne do jednego z licznych nowych gmachów reprezentacyjnych w Warszawie"; J. Zaruba, Topolski, Świat 1955 nr 34, s. 11. Redakcja warszawskiego tygodnika w kilku odcinkach przedrukowała rysunki z „Topolski's Chronicle"; zob.: Świat 1955 nr 34, s. 12-13; nr 39, s. 9; nr 43, s. 8; nr 50/51, s. 18-19.

${ }^{7}$ J. Kowalewski, List otwarty do Feliksa Topolskiego, Orzeł Biały $1955 \mathrm{nr}$ 42, s. 1, 5.

${ }^{8}$ Tamże.

${ }^{9}$ AMSZ, D III, z. 9, w. 42, t. 557, k. 12, Depesza E. Milnikiela do S. Skrzeszewskiego z 23 grudnia 1955.

${ }^{10}$ Tamże, k. 13, Depesza E. Milnikiela do J. Winiewicza z 2 stycznia 1956. 
szych interesów politycznych akt ten byłby [również] cenną pomocą dla akcji repatriacyjnej i przybliżenia emigracji do Polski. Chodzi tu w pierwszym rzędzie o rozsianych po całym świecie polskich intelektualistów i artystów, którym nasz stosunek do Topolskiego pomógłby do wyzbycia się szeregu kompleksów i emigracyjnych neuroz ${ }^{11}$.

Choć Topolskiemu obiecano pokazanie jego prac na weneckim Biennale, to ostatecznie w Warszawie zapadła negatywna decyzja, o czym jednak nikt go nie zawiadomił. Emigracyjny artysta zawiedziony był takim finałem sprawy, gdyż bardzo zależało mu na udziale w Biennale. Jeszcze bardziej zabolały go jednak sugestie pojawiające się w krajowej prasie, że w zamian za zgodę na zorganizowanie wystawy czy udział w Biennale zażądał trzech tysięcy funtów. Topolski dowiedział się o tym z paryskiej „Kultury”, która przedrukowała fragmenty artykułu z „Przeglądu Kulturalnego”. W telefonicznej rozmowie żalił się ambasadorowi Milnikielowi. Peerelowski dyplomata oburzony lekceważącym potraktowaniem wybitnego artysty jeszcze tego samego dnia depeszował do Winiewicza:

Jak można [było] dopuścić, żeby nikt dotychczas Topolskiego nie poinformował o odmowie co do Biennale? Czy rzeczywiście brak u nas telefonu, poczty, poczty kurierskiej?

Czemu go się o tym nie powiadomiło? Przecież to myśmy wszczęli całą sprawę ${ }^{12}$.

Gorąco prosił też kierownictwo MSZ o ,spowodowanie honorowego i odważnego wyjścia z tej sprawy" ${ }^{\prime 13}$.

Autorka artykułu w „Przeglądzie Kulturalnym”, przedstawiając dramatyczną sytuację materialną młodych plastyków w kraju, stwierdziła:

$\mathrm{Z}$ drugiej strony nie wiadomo również dlaczego utalentowany skądinąd rysownik i artysta dworu angielskiego, obywatel brytyjski pochodzenia polskiego, krótko mówiąc, Feliks Topolski ma wywieźć z Polski 3000 funtów szterlingów w walucie, jak bowiem wieść głosi, jest to cena, jaką wyznaczył były student Akademii Warszawskiej za prawo urządzenia swojej wystawy w Warszawie, ulegając naszym usilnym prośbom (3000 funtów to cena zakupów). Nie mówiąc o tym, że jest to suma, za którą można by nabyć na świecie kilka niezgorszych obrazów współczesnych malarzy, jest to również suma, za którą około dwudziestu polskich malarzy mogłoby wyjechać na 3 miesiące do Anglii, Francji, Włoch czy Holandii i nie byłyby to ubogie stypendia. Ale nasza stara zasada „zastaw się a postaw się” obowiązuje, jak widać, w każdym ustroju ${ }^{14}$.

Niemal równocześnie kąśliwa nota ukazała się na łamach warszawskiej „Nowej Kultury”. Wykpiwając pomysł pokazania prac Topolskiego na weneckim Biennale pisano:

I oto, którejś bezsennej nocy do jednej z wpływowych głów wpada genialny pomysł: żyje przecież w Anglii obywatel brytyjski, wywodzący się z naszego kraju, znany na całym świecie grafik $\mathrm{i}$ rysownik nazwiskiem Feliks Topolski. Topolski od dawna wprawdzie zerwał kontakt $\mathrm{z}$ krajem, zagranica zna go jako artystę stale mieszkającego i pracującego w Anglii, jednak nazwisko na „ski” i znajomość języka polskiego wydała się wystarczającym powodem, aby on właśnie reprezentował na Biennale sztukę Polski Ludowej. Nie bacząc na to, że zjawienie się jego na salach wystawowych pod szyldem Polski wywołałoby niechybnie gromki śmiech zwiedzających, zwrócono się do Topolskiego, aby reprezentował nasz kraj wobec zagranicy. Topolski zachował się całkiem

\footnotetext{
${ }^{11}$ Tamże, k. 15, Notatka służbowa M. Żułkosia dla MSZ z 22 lutego 1956.

${ }^{12}$ Tamże, k. 17, Depesza E. Milnikiela do J. Winiewicza z 25 kwietnia 1956.

${ }^{13}$ Tamże. Zob. też: Młodzi plastycy w kraju, Kultura $1956 \mathrm{nr} 4$ (102), s. 105.

14 J. Guze, O mlodych malarzach $i$ malarstwie sztalugowym, Przegląd Kulturalny 1956
} nr 11, s. 5. 
rozsądnie i postanowił przynajmniej zarobić na tym parę groszy. Zażądał więc wypłacenia mu ok. 3000 funtów szterlingów w zamian za zgodę na wystawienie swoich prac w pawilonie polskim. Topolskiemu wręczono lekką rączką pokaźną sumkę. Na skutek tej transakcji wielki bluff w obronie honoru narodowego o mały włos stałby się rzeczywistością, jednakże w ostatniej chwili ktoś złapał się za głowę, ktoś parsknął śmiechem i Topolskiego na Biennale nie wyślemy.

Chyba to i lepiej, bo przecież, mimo wszystko powołaniem naszego kraju nie jest wyłącznie dostarczanie powodów do śmiechu zagranicznym obserwatorom. Radość jednak z tego faktu mąci nam niewczesna refleksja: — za co właściwie zapłaciliśmy tę forsę? Topolski bowiem pieniążków zainkasowanych od naszych władz oczywiście nie zwróci - i ma rację — wyniósł bowiem ze swojej ojczyzny oprócz nazwiska również absolutnie słuszną zasadę: „śmierć frajerom!"15.

W końcu maja na „brutalne oszczerstwa” wydrukowane w krajowej prasie Topolski odpowiedział w liście do redaktora Arskiego (zastrzegł, że pod żadnym warunkiem nie godzi się na opublikowanie listu). Sprostowań i wyjaśnień w druku oczekiwał od osób i instytucji, które wystąpiły z propozycją zorganizowania wystawy oraz zakupu obrazów. Sam nie chciał się publicznie wypowiadać w swojej sprawie. Prywatnie wyjaśniał Arskiemu, że nie trzeba go było zdobywać:

Interesowałem się niezmiernie wystawą w Polsce, w największej mierze dlatego, żeby pomóc młodym artystom w torowaniu własnych dróg twórczych. Uważałem, że właśnie teraz należy im pokazać, że „Zachód” nie musi być modnisiostwem, kiedy grozi im powrót do dawnej zarazy PROWINCJONALIZMU czyli nowinkarstwa paryskiego $\mathrm{z}$ drugiej ręki.

Łączenie sprawy zakupu swoich obrazów z planowaną wystawą uważał za naiwne, albo podłe:

Powiedziano mi, że dopełnia się braki w kolekcjach państwowych — i że wobec zupełnego braku moich prac, zakupi się reprezentacyjną grupę. Uważałem propozycję taką za zaszczytną, a też oczywistą.

Topolski dodał, że obrazy wybrane dla zakupu należą do najlepszych jego prac ${ }^{16}$.

Emigracyjny artysta nie pojechał więc na Biennale do Wenecji, ciągle pod znakiem zapytania stała też sprawa zorganizowania wystawy jego obrazów w Warszawie. W tej sytuacji nie był pewien czy nadal aktualne było zaproszenie go do Polski na spędzenie urlopu (miał zamieszkać wraz $\mathrm{z}$ rodziną w willi będącej w dyspozycji dyrektora Lorentza w Jastarni). Milnikiel podtrzymywał kontakt z Topolskim, ale sam nie wiedział, co ma mu powiedzieć. Ponownie interweniował też w centrali MSZ. W piśmie do wiceministra Winiewicza z 18 maja 1956 roku stwierdził:

Nie ma chyba potrzeby udowadniania jaką ma pozycję Topolski w Wielkiej Brytanii i jak cenną pozycją jest on dla nas. Topolski jest rozżalony, ale Topolski nie jest stracony dla nas ${ }^{17}$.

Szukając wyjścia z tej żenującej sytuacji, ambasador apelował o wysłanie Topolskiemu listu wyjaśniającego przyczyny odmowy wystawienia jego prac w weneckim Biennale. Propozycja wywołać miała sprzeciw przede wszystkim młodych malarzy w kraju,

\footnotetext{
${ }^{15}$ k., Ale za cośmy zapłacili?, Nowa Kultura $1956 \mathrm{nr} 14$, s. 8.

${ }^{16}$ AMSZ, D III, z. 9, w. 42, t. 557, k. 26-27, List F. Topolskiego do S. Arskiego z 25 maja 1956. Kopię listu Topolski przesłał do wiadomości Ministerstwa Kultury i Sztuki. Korespondencja Topolskiego z krajowymi instytucjami przechodziła przez ręce ambasadora Milnikiela i MSZ.

${ }^{17}$ Tamże, k. 20, Pismo E. Milnikiela do J. Winiewicza z 18 maja 1956.
} 
którzy argumentowali, że Topolski ma już tak silną pozycję w świecie artystycznym, że nie potrzebuje specjalnej promocji. Należało również ostatecznie załatwić ciągnącą się od kilku miesięcy sprawę wystawy obrazów Topolskiego w Polsce i oficjalnie potwierdzić zaproszenie go do kraju na spędzenie urlopu wraz z całą rodziną. W ocenie Milnikiela pokrycie przez władze PRL kosztów przejazdu byłoby „w pewnej mierze rekompensatą za wyrządzone mu przykrości”. Ambasador wskazał na polityczne korzyści, które przyniósłby pobyt Topolskiego w Polsce: „fakt, że Topolski spędza z rodziną urlop, nie uszedłby uwagi kół emigracyjnych, zwłaszcza kół malarskich, z którymi nawiązujemy coraz lepsze kontakty” ${ }^{18}$. Poza tym „Topolski po spędzeniu urlopu w Polsce i odświeżeniu swoich znajomości na pewno nastawiałby się coraz bardziej pozytywnie w stosunku do nas i mógłby nam dużo pomóc swoimi stosunkami, jakie on w Anglii posiada" $"$.

W liście z 10 kwietnia 1956 roku (przesyłka dotarła do adresata dopiero w ostatnich dniach maja!) wiceminister kultury i sztuki Lucjan Motyka zaproponował Topolskiemu zorganizowanie wystawy jego obrazów w październiku. W tym samym czasie artysta miał już jednak zaplanowaną wystawę w Nowym Jorku. W tej sytuacji Topolski proponował przesunięcie daty wystawy w Warszawie najwcześniej na wiosnę 1957 roku. Domagał się również oficjalnego wyjaśnienia zarzutów, które na jego temat ukazały się w krajowej prasie (dotknęła go zwłaszcza sugestia, że za zgodę na zorganizowanie wystawy otrzymał trzy tysiące funtów, a gdy zgodę cofnięto, pieniędzy nie zwrócił). Topolski podkreślił, że nie chodzi mu o przeprosiny, a jedynie o oczyszczenie atmosfery. Przywiązując dużą wagę do swojej pierwszej wystawy w Polsce, chciał, aby pokazywała ona możliwie całokształt jego twórczości. Argumentował, że przesunięcie daty na następny rok pozwalałoby na sprowadzenie monumentalnej panoramy - $\mathrm{Ka}$ walkady Wspólnoty Brytyjskiej, znajdującej się w Singapurze, czy dużego panneau Wschód z Nowego Delhi oraz szeregu płócien z galerii w Stanach Zjednoczonych i Francji ${ }^{20}$.

Milnikiel w pełni podzielał stanowisko emigracyjnego artysty. W piśmie do MSZ z 15 czerwca 1956 roku podkreślił: „Racja jest całkowicie po stronie Topolskiego i Topolski ma prawo być rozgoryczony" "21 . Ambasador uważał, że ciągnącą się miesiącami sprawę wystawy należy ostatecznie przeciąć i zdecydować się na jedną z dwóch możliwości: odrzucić propozycję przesunięcia terminu wystawy i zerwać z Topolskim (,wolę to niż zwodzenie go i napadanie w prasie",22), albo zgodzić się na zorganizowanie wystawy, najlepiej jesienią 1957 roku, sprowadzić jego prace z Indii i USA, zlecić napisanie kilku pozytywnych artykułów o Topolskim oraz stanowcze odwołanie „kłamliwej i oszczerczej notatki” przez redakcję „Nowej Kultury”. Poza tym dyrektor Starzyński powinien napisać do Topolskiego list wyjaśniający powody, dla których władze PRL nie dotrzymały obietnicy zaproszenia go $\mathrm{z}$ rodziną na wakacje do Polski ${ }^{23}$.

Wydawało się, że apele i interwencje ambasadora w centrali MSZ przyniosą wreszcie skutek, gdy w rozwiązanie sprawy zaangażował się wiceminister Winiewicz. W końcu czerwca przesłał on ministrowi kultury i sztuki Karolowi Kurylukowi list Topolskiego z 30 maja wraz z uwagami Milnikiela. Winiewicz sugerował jak najszybsze (,,jeszcze w tym sezonie") zaproszenie emigracyjnego artysty do Polski na wczasy,

\footnotetext{
${ }^{18}$ Tamże, k. 20-21.

19 Tamże, k. 21.

${ }^{20}$ Tamże, k. 24-25, List F. Topolskiego do Ministerstwa Kultury i Sztuki z 30 maja 1956.

${ }^{21}$ Tamże, k. 23, Pismo E. Milnikiela do J. Winiewicza z 15 czerwca 1956.

${ }^{22}$ Tamże.

${ }^{23}$ Tamże, k. 23-23a.
} 
zobowiązanie się do urządzenia mu wystawy w 1957 roku i odpowiedzi „szkodnikowi, który Topolskiego zaatakował” na łamach „Nowej Kultury”. Jak najszybciej należało też zorganizować w Muzeum Narodowym wystawę zakupionych już obrazów Topolskiego oraz ,przestrzegać kulturalnego obyczaju odpowiadania na listy”. Prosząc ministra kultury i sztuki, aby osobiście zajął się sprawą, argumentował:

Topolskim winniśmy się interesować jeżeli nie dla innych względów, to przede wszystkim dla politycznego oddziaływania na naszą emigrację (zwłaszcza artystów) oraz na koła kulturalne brytyjskie. Kontakt Topolskiego z Polską, jego wystawy w Polsce, mogą skłonić i innych polskich artystów za granicą do zbliżenia się do nas, a niektórych nawet do repatriacji. Olbrzymia pozycja Topolskiego w świecie artystycznym Zachodu może ułatwić, przede wszystkim rozszerzyć, nasze stosunki z artystami na Zachodzie, którzy teraz unikają z nami współpracy ${ }^{24}$.

Ministerstwo Kultury i Sztuki, po naciskach ze strony MSZ, wreszcie zaprosiło Topolskiego do odwiedzenia kraju. Artysta nie mógł jednak skorzystać z zaproszenia, gdyż przebywał w Stanach Zjednoczonych. Z Nowego Jorku (gdzie miał wystawę swoich prac) wyjechał do Kalifornii, planował też podróż do Meksyku. Nie znając dokładnie daty powrotu do Londynu, proponował korespondencyjne przedyskutowanie szczegółów planowanej wystawy. Przypominał też, że byłoby dla niego „specjalnie ważnym” oficjalne i rzeczowe odparcie oszczerstw, które pojawiły się w krajowej prasie ${ }^{25}$. W rezultacie sprawa wystawy na kolejne miesiące utknęła w Ministerstwie Kultury i Sztuki.

W raporcie dla MSZ z 14 stycznia 1957 roku ambasador Milnikiel wystawił miażdżącą ocenę:

Sprawa Topolskiego — podkreślił — należy chyba do najbardziej nieudolnie załatwionych. Jeśli uda nam się doprowadzić do zorganizowania wystawy jego [prac] w Warszawie, to przypisać m.in. należeć trzeba będzie jego wyjątkowej [sic!] cierpliwości. W całej tej sprawie najboleśniejsze jest to, że przegrywamy sprawę na najgłupszych odcinkach - nie umieliśmy dotrzymać żadnego terminu i nie umieliśmy się zdobyć nawet, mimo moich kilkukrotnych telefonów na zatelefonowanie do Topolskiego ${ }^{26}$.

Ambasador dodał, że osobiście nadal łączą go jak najlepsze stosunki z artystą:

Bywamy ze sobą, w najbliższych zaś dniach będzie on wraz z żoną i dziećmi moim gościem w loży, jaką zarezerwowałem na przedstawienie w cyrku ${ }^{27}$.

W odpowiedzi na liczne monity Departament Informacji i Prasy MSZ dopiero wiosną 1957 roku otrzymał z Gabinetu Ministra Kultury i Sztuki wiadomość, że prawdopodobnie w maju będzie rozpatrywana sprawa planowanych wystaw dzieł twórców emigracyjnych i ich przyjazdu do Polski ${ }^{28}$.

Jesienią 1957 roku Milnikiel (po otrzymaniu listu od ministra Kuryluka) ponownie wrócił do rozmów z Topolskim w sprawie wystawy jego prac i wizyty w Polsce. I tym razem rozmowy nie doprowadziły jednak do żadnych pozytywnych wyników. Ambasador wyraził ubolewanie $\mathrm{z}$ powodu prasowych ataków na Topolskiego, uważał jednak, że wracanie na łamach prasy do sprawy sprzed półtora roku byłoby niezrozumiałe i bezcelowe. Przekonywał artystę, że jego przyjazd do kraju i wystawa dadzą mu pełną

${ }^{24}$ Tamże, k. 22, Pismo J. Winiewicza do K. Kuryluka z 29 czerwca 1956.

${ }^{25}$ Tamże, k. 29, List F. Topolskiego do L. Motyki z 1 września 1956.

${ }^{26}$ AMSZ, D III, z. 9, w. 42, t. 556, k. 16, Notatka E. Milnikiela dla MSZ z 14 stycznia 1957.

${ }^{27}$ Tamże.

${ }^{28}$ AMSZ, D III, z. 9, w. 42, t. 557, k. 30, Notatka DPiI MSZ z kwietnia 1957 dot. zaproszenia do Polski F. Topolskiego. 
satysfakcję. W imieniu władz państwowych podtrzymał zaproszenie do odwiedzenia ojczyzny. Podczas pobytu na wczasach w Polsce Topolski mógłby omówić szczegóły zorganizowania wystawy swoich prac. Topolski nadal czuł się jednak urażony i domagał się oficjalnej reakcji na prasowe zarzuty sprzed miesięcy. Ambasador oceniał, że „musi [jeszcze] upłynąć pewien okres czasu dopóki jego bardzo silnie zadrażniona ambicja przestanie być czynnikiem wpływającym na jego reakcję"29. Pojawił się również nowy problem. Zgodę na wystawę i wizytę w Polsce Topolski uzależniał od wyjazdu do Związku Sowieckiego i Chin. Oczekiwał, że władze PRL wystąpią w roli pośrednika, który załatwi mu zaproszenie do Moskwy i Pekinu. Koszty podróży i pobytu artysty pokrywać mieli oczywiście organizatorzy. Przebywając przez kilka miesięcy w Polsce, zamierzał na miejscu omówić sprawę swojej ewentualnej wystawy. Przede wszystkim chciał się jednak skoncentrować na nowych zeszytach „Topolski's Chronicle". Milnikiel, relacjonując rozmowy z Topolskim, zaznaczył, iż uważa on siebie

za rysownika bardo wielkiej klasy, wydawane zaś przez niego „Topolski’s Chronicle” uważa za jedyne tego rodzaju pismo w świecie o dużej wartości. Rozchodzi się ta kronika, jak twierdzi Topolski, po całym świecie i wg Topolskiego, ma ona ogromną popularność. Objechał on już szereg krajów kapitalistycznych ze swoją kroniką i obecnie zamierzałby pojechać do Polski, ZSRR i Chin. Warszawa wg koncepcji Topolskiego byłaby centrum wydawania kroniki właśnie z tych krajów. Dla Polski, zdaniem Topolskiego, miałoby to duże znaczenie propagandowe $\mathrm{e}^{30}$.

Milnikiel nie widział jednak możliwości podjęcia przez ambasadę (czy też MSZ) interwencji w Moskwie i Pekinie w celu zaproszenia Topolskiego, tym bardziej, że artysta miał brytyjskie obywatelstwo. Uznając propozycję Topolskiego za niemożliwą do przyjęcia, ambasador uważał, że tym razem nie ma się co spieszyć z odpowiedzią. Za dwa lub trzy miesiące MSZ powinno mu udzielić negatywnej odpowiedzi dotyczącej ewentualnej interwencji w Moskwie i Pekinie, podtrzymując jednak nadal zaproszenie do Warszawy. W ocenie Milnikiela Topolski po pewnym czasie miał ochłonąć i samemu, powodowany sentymentem do kraju, wrócić do tematu swojej wystawy. Ambasador dodał, że ostatnio zdenerwował go fakt organizowania w Polsce wystaw Józefa Czapskiego i Marka Żuławskiego. Milnikiel nadal utrzymywał z Topolskim jak najbliższe stosunki towarzyskie ${ }^{31}$.

Do Polski światowej sławy malarz i rysownik przyjechał dopiero kilka lat później, w połowie sierpnia 1961 roku. Przywiózł ze sobą 104 rysunki, przedstawiające sceny z życia i walk żołnierzy polskich podczas II wojny światowej na Bliskim Wschodzie, w północnej Afryce i w Europie (m.in. bitew 2. Korpusu Polskiego pod Loreto i Monte Cassino). Swoje prace Topolski ofiarował Muzeum Narodowemu, które pokazało je na wystawie otwartej 6 września. Ekspozycję uzupełniono o 15 obrazów olejnych, gwaszy, rysunków barwnych i projektów malowidła ściennego, które w 1956 roku Ministerstwo Kultury i Sztuki zakupiło od artysty, a także o wypożyczone przez autora dwa obrazy z wykonywanej na zamówienie University of Texas serii 20 portretów pisarzy angielskich (Bertranda Russella i Grahama Greene'a). Na wystawie pokazano również numery „Topolski’s Chronicle” i „Nowej Polski” z reportażami i rysunkami Topolskiego oraz reprodukcje niektórych jego malowideł ściennych i albumowe wydawnictwa rysunków i malarstwa. Na wernisażu obecny był autor. O wizycie i wystawie mieszka-

\footnotetext{
${ }^{29}$ Tamże, k. 31, Pismo E. Milnikiela do K. Kuryluka z 15 listopada 1957.

${ }^{30}$ Tamże.

${ }^{31}$ Tamże, k. 32-33,
} 
jącego w Londynie artysty informowała krajowa prasa. Spełniło się też marzenie Topolskiego o podróży na Wschód. Po pobycie w Warszawie i Kazimierzu nad Wisłą artysta pojechał do Związku Radzieckiego i Chin ${ }^{32}$.

Feliks Topolski zmarł 24 sierpnia 1989 roku w Londynie ${ }^{33}$.

\section{LITERATURA}

Archiwum Ministerstwa Spraw Zagranicznych, Departament III, z. 9, w. 42, t. 557, k. 19;

Cz. Bednarczyk, W podmostowej arkadzie. Wspomnienia drukarza i wydawcy, Londyn 1988; Feliks Topolski: prace $w$ zbiorach Muzeum Narodowego $w$ Warszawie, [katalog], red. I. Jakimowicz, Warszawa 1965;

J. Kilian, Feliks Topolski - kronikarz XX wieku, [w:] Między Polskq a światem. Kultura emigracyjna po 1939 roku, red. M. Fik, Warszawa 1992, s. 177-184;

S. Kossowska, Galeria przodków, Warszawa 1991;

J. Kowalik, Czasopiśmiennictwo, [w:] Literatura polska na obczyźnie 1940-1960, red. T. Terlecki, t. 2, Londyn 1965;

J. W. Sienkiewicz, Polskie galerie sztuki w Londynie w drugiej połowie XX wieku, Lublin-Londyn 2003;

Sztuka polska w Wielkiej Brytanii 1940-2000. Antologia, wybrał, przygotował do druku i wstępem opatrzył M. A. Supruniuk, Torun 2006.

${ }^{32}$ Feliks Topolski: prace $w$ zbiorach Muzeum Narodowego $w$ Warszawie, [katalog], red. I. Jakimowicz, Warszawa 1965; zob. też: Feliks Topolski w Polsce, Kurier Polski 1961 nr 198, s. 1; Feliks Topolski znakomity malarz i rysownik w Warszawie, Express Wieczorny $1961 \mathrm{nr}$ 194, s. 2; Rysunki F. Topolskiego na wystawie w Muzeum Narodowym, Express Wieczorny 1961 nr 210, s. 5; Pokaz prac F. Topolskiego w Muzeum Narodowym, Trybuna Ludu 1961 nr 246, s. 3; Z. K. Rogowski, Feliks Topolski w Warszawie, Stolica 1961 nr 36, s. 10-11; S. Ostrowski, Olówkiem przez kontynenty, Świat 1961 nr 36, s. 16; Cz. Chruściński, Feliks Topolski w Warszawie, 7 Dni w Polsce $1961 \mathrm{nr}$ 38, s. 7; S. Ozimek, Korespondent wojenny - Feliks Topolski w Warszawie, Żołnierz Wolności $1961 \mathrm{nr}$ 40, s. 9; E. Sztekker, Rozmawiałam z Feliksem Topolskim, Głos Nauczycielski 1961 nr 40, s. 6; S. Bołdok, Rysunki i malarstwo Feliksa Topolskiego, Przegląd Artystyczny $1962 \mathrm{nr}$ 1, s. 53-55. Z pozytywnymi opiniami większości prasy kontrastowała ocena Z. Herberta: „Tymczasem, szczerze mówiąc, przy całym szacunku dla tej niewątpliwie indywidualności, artysta zasługiwał na rzetelniejsze i mniej grzecznościowe potraktowanie. To zwłaszcza, co pokazano z jego malarstwa, budzi zasadniczy sprzeciw. Zwały niechlujnie nałożonej farby, barokowe skłębienie kształtów (ale bez barokowej formy), zupełna nonszalancja i zdanie się na natchnienie są nie do przyjęcia nawet dla tych, którzy nie są entuzjastami zimnej, geometrycznej abstrakcji. [...] Podobnie ma się sprawa z grafiką, dużo zresztą lepszą od malarstwa. Jest rzeczą żenującą, że Topolski eksponuje chyba wszystko, co narysował. [...] Większość rysunków Feliksa Topolskiego to zanotowany stan podrażnienia oka, ale jeszcze nie wizja narzucająca się z bezwzględną koniecznością"; [Z. Herbert] zh, Noty. Feliks Topolski, Twórczość $1961 \mathrm{nr} 11, \mathrm{~s} .163$.

${ }^{33}$ S. Frenkiel, Jeszcze jedno pożegnanie Feliksa Topolskiego, Dziennik Polski i Dziennik Żołnierza 1989 nr 246, s. 13; S. Kossowska, Feliks Topolski (1907-1989), Kultura 1989 nr 11 (506), s. 126-128; przedruk w: S. Kossowska, Galeria przodków, Warszawa 1991, s. 115-118. 
THE WOULD-BE EXHIBITION OF FELIKS TOPOLSKI IN THE NATIONAL MUSEUM IN 1956

In 1956 in the National Museum in Warsaw there was to be and exhibition of the works of Feliks Topolski, a world-famous painter and illustrator living in Great Britain. The People's Republic of Poland embassy in London contacted Topolski. Yet Topolski came to Poland only in 1961.

Keywords: Feliks Topolski, Polish art in Great Britain, The People's Republic of Poland embassy. 